\title{
EXPERIMENTAL ANALYSIS AND THEORETICAL MODELLING OF CUTTING PARAMETERS IN THE DRILLING OF AISI H13 STEEL WITH COATED AND UNCOATED DRILLS
}

\begin{abstract}
Summary
In this study, drillability experiments were carried out on the AISI H13 hot work steel which is difficult to machine. Uncoated and AlCrN-coated carbide drills, $\varnothing 14 \mathrm{~mm}$, were used at 4 cutting speeds $(60,75,90$ and $108 \mathrm{~m} / \mathrm{min})$ and three different feed rates $(0.15,0.20$ and $0.25 \mathrm{~mm} / \mathrm{rev}$ ). As a result of the experimental work, it was observed that an increase in the feed rate caused an increased on the thrust force in the workpiece machined with both the uncoated and coated drills. While an increase in the cutting speed caused the thrust force to increase in operations performed with uncoated drills, the increased cutting speed led to a decreased torque. In contrast, an increase in the cutting speed caused both the thrust force and the torque to decrease in the operations with coated drills. Stresses occurring on the drills were analyzed and a mathematical model was developed using the finite element method and the ANSYS Workbench package software.
\end{abstract}

Key words: $\quad$ Drillability, AISI H13, AlCrN-coated carbide drills, cutting parameters, ANSYS modelling

\section{Introduction}

Tool steels are shaped by removing chips as well as by production methods, such as cutting, forging and bending. Problems of the cutting tool life are often encountered in shaping because of the physical and mechanical properties of the materials and the methods developed for metal removal. Consequently, research is increasingly being carried out in this area. Wear of a cutting tool is an inevitable process in machining. As a result of the interaction between abrasion and the cutting tool/workpiece/machining conditions, the loss of cutting tool performance is a significant problem.

The process of drilling holes carried out in a closed area imposes a number of restrictions on chip formation and chip discharge. The evacuation process is critical. Chip formation occurring during drilling influences the cutting forces, cutting temperature, roundaboutly, the quality of the hole. The cutting speed and the feed rate are the most efficient input parameters in drilling; during the cutting operation they affect the drilling forces directly and determine the success of the drill. 
AISI H13 steel is known as a material which is difficult to machine. A number of improvements have been made in its microstructure and positive features have been achieved in dealing with the difficulties in processing this steel by applying heat treatment and by adding various alloy elements. Due to these features, even with cutting area temperatures reaching up to $600{ }^{\circ} \mathrm{C}$ during the processing of AISI H13, hardness did not decrease and the steel exhibited high strength [1-5]. In order to rise to such challenges, an increasing number of studies on cutting tool materials and cutting parameters are being made. The findings of experimental studies using uncoated carbide drills showed that an increase in the cutting speed accelerated the wear and led to an increased thrust force; in addition, it was determined that an increase in the feed rate caused increased cutting forces. It was highlighted that coated cutting tools were resistant to abrasion and that a better quality of hole was obtained with them. Previous studies reported that increasing the cutting speed in operations using coated drills led to a decline in the cutting forces and torque [6-10]. They emphasized that mathematical models had been developed using the results of various experimental data analyses, and that most of the analysis results of these models had proven to be compatible [11-14].

In the present study, a model was created to predict the cutting forces and torque present during drilling operations. This model could be applied in order to prevent the difficulties that commonly occur during drilling operations; furthermore, the developed model could be useful in predicting the outcome of these operations.

\section{Materials and methods}

Hot work AISI H13 tool steel with a hardness value of $90 \mathrm{HRB}$ and a DIN code of 1.2374 was used in the experiments. The chemical analysis of this steel is given in Table 1.

Table 1 Chemical composition of AISI H13 (weight \%)

\begin{tabular}{|l|l|l|l|l|l|l|l|l|}
\hline \multirow{2}{*}{$\begin{array}{l}\text { AISI H13 } \\
\text { \% }\end{array}$} & $\mathbf{C}$ & $\mathbf{S i}$ & $\mathbf{M n}$ & $\mathbf{P}$ & $\mathbf{S}$ & $\mathbf{C r}$ & $\mathbf{M o}$ & $\mathbf{N i}$ \\
\cline { 2 - 9 } & 0.418 & 1.08 & 0.348 & 0.017 & 0.001 & 5.12 & 1.36 & 0.044 \\
\hline $\mathbf{A l}$ & $\mathbf{C o}$ & $\mathbf{C u}$ & $\mathbf{N b}$ & $\mathbf{T i}$ & $\mathbf{V}$ & $\mathbf{W}$ & $\mathbf{S n}$ & $\mathbf{F e}$ \\
\hline 0.037 & $\leq 0.01$ & 0.018 & 0.006 & 0.009 & 1.09 & $<0.01$ & $<0.001$ & 90.455 \\
\hline
\end{tabular}

Chip removal processes were performed in a Johnford VMC-550 CNC vertical machining center. For each experiment, samples of $25 \mathrm{~mm}$ in the outer diameter and $35 \mathrm{~mm}$ in the hole length were prepared. The cutting tools used in the experiments were $ø 14 \mathrm{~mm}$ uncoated and coated (AlCrN) solid helical carbide, DIN $6537 \mathrm{~K}$ standard with 3D drilling capacity. Thermal and mechanical characteristics of the cutting tools are given in Table 2 . The AlCrN-coated drills were made of $10 \%$ Co with an average hardness of 1610HV10. The properties of the AlCrN coating material are given in Table 3. In accordance with the recommendations of the tool manufacturer, four different cutting speeds $(60,75,90$ and $108 \mathrm{~m} / \mathrm{min}$ ) and feed rates $(0.15,0.20$ and $0.25 \mathrm{~mm} / \mathrm{rev})$ were selected as the cutting parameters. In the cutting experiments, the drilling process influence values of axial force (thrust force, $\left.\mathrm{F}_{\mathrm{z}}\right)$ and the drilling torque $\left(\mathrm{M}_{\mathrm{z}}\right)$, depending on the changes in the parameters, were each measured individually at the same time.

Table 2 Thermal and mechanical properties of tools in drilling

\begin{tabular}{|l|l|l|}
\hline & K25 grade (Uncoated) & P25 grade (Coated) \\
\hline Density $\left(\mathrm{g} / \mathrm{cm}^{3}\right)$ & 14.6 & 12.6 \\
\hline Compressive Strength $(\mathrm{MPa})$ & 5000 & 4600 \\
\hline Young Modulus $(\mathrm{GPa})$ & 590 & 550 \\
\hline Thermal Conductivity $(\mathrm{W} / \mathrm{mK})$ & 70 & 45 \\
\hline Thermal Expansion Coefficient $\left(10^{6} / \mathrm{K}\right)$ & 5.6 & 6.7 \\
\hline Poisson Rate & 0.22 & 0.22 \\
\hline
\end{tabular}


Experimental Analysis and Theoretical Modelling of

Cutting Parameters in the Drilling of AISI H13 Steel with

Coated and Uncoated Drills

Table 3 Properties of the AlCrN coating material

\begin{tabular}{|l|l|}
\hline Coating Material & AlCrN \\
\hline Microhardness HV & 3200 \\
\hline Friction Coefficient Against Steel & 0.35 \\
\hline Internal Stress $(\mathrm{GPa})$ & -3.0 \\
\hline Max. Service Temperature $\left({ }^{\circ} \mathrm{C}\right)$ & 1100 \\
\hline Coating Colour & Light grey \\
\hline Coating Structure & Monolayer \\
\hline
\end{tabular}

\subsection{Analyses}

Several studies were examined in order to gather necessary data to be used for a linear elastic material model. Table 2 shows the thermal and mechanical specifications of both coated (P25 grade) and uncoated (K25 grade) cutting tools which are used in stress analysis experiments. To create a network of all drills in the drilling processes, a 3D 10-node quadratic tetrahedron element SOLID 187 was used. The mesh dimensions for element separation were applied to be less intensive for all drill geometry (element size $=2 \mathrm{~mm}$ ) and to be finer (element size $=0.05 \mathrm{~mm}$ ) at the cutting-tool contact surface where the shear force and the drilling moment were to be applied. Before the stress analysis, the following assumptions were made:

1. Drills used in the analysis are unused and free of wear.

2. It is assumed that the displacements are proportional to the applied loads and are very small in size compared to the solid model geometry and that if the applied load is removed, the drills are returned to their original state.

3. A static state analysis was made and it was assumed that there was no vibration.

4. The surface corresponded to the length of the drilling centre mount. As a precondition, displacement of the drill in all dimensions was selected as zero on the surface.

In accordance with the changes in the cutting parameters, the results were obtained by examining the wear on the cutting tool and the effects of total deformation $(\Delta)$, von-Mises stress $\left(\mathrm{S}_{\text {eqv }}\right)$ and minimum and maximum stresses $\left(\mathrm{S}_{1}\right.$ and $\mathrm{S}_{3}$, respectively) that had occurred on the drill, particularly on the chip surface, the major cutting edge and the minor cutting edge.

\subsection{Modelling of Stress Components}

In the modelling of the overall deformation and stress components occurring on the cutting tool, it was assumed that the values of the thrust force, drilling feed rate, and torque that influence the cutting tool had the stress and deformation varied. In accordance with this statement, a model was refined for the total deformation $(\Delta)$, the von-Mises stress, the maximum and the minimum main stress $\left(\mathrm{S}_{1}\right.$ and $\mathrm{S}_{3}$, respectively), as given in Equation 1:

$$
R_{i}=c \cdot F_{z} \cdot m \cdot F_{c} \cdot n \cdot M_{z} \cdot p \cdot f \cdot q
$$

where $\mathrm{R}_{\mathrm{i}}$ is the determined total deformation (mm) and stress (MPa); c is the constant value for both the coated and uncoated drilling tools. $F_{z}, F_{c}$ and $M_{z}$ are the thrust force $(N)$, the cutting force $(\mathrm{N})$ and the drilling torque $\left(\mathrm{N}_{\mathrm{mm}}\right) ; \mathrm{m}, \mathrm{n}, \mathrm{p}$, and $\mathrm{q}$ are the exponents for the thrust force, the cutting force, the drilling torque and the feed rate, respectively, for the coated and uncoated drills, and $\mathrm{f}$ is the feed rate value $(\mathrm{mm} / \mathrm{rev})$. To solve Equation 1, the specified stress results $\left(\mathrm{R}_{\mathrm{i}}\right)$ and the whole deformation were determined by means of the Ansys analysis. The type of drills (coated and uncoated) determine the constant (c) and the calculation of the exponents $\mathrm{m}, \mathrm{n}, \mathrm{p}$, and $\mathrm{q}$, which was essential. In order to fulfil this task, Equation 1 was transformed to the logarithmic type as follows: 


$$
\log R_{i}=\log c+m \cdot \log F_{z}+n \cdot \log F_{c}+p \cdot \log M_{z}+q \cdot \log f
$$

in the logarithmic format, and it was transformed to the linear form by using Equation 3:

$$
Y=\beta_{0} X_{0}+\beta_{1} X_{1}+\beta_{2} X_{2}+\beta_{3} X_{3}+\beta_{4} X_{4}+\varepsilon
$$

In Equation 3, $\mathrm{Y}$ is the logarithmic value of the predicted stress components and total deformation (for example, $\log S_{1}$ ); $\beta_{1}, \beta_{2}, \beta_{3}$ and $\beta_{4}$ are the equation coefficients ( $\mathrm{m}, \mathrm{n}, \mathrm{p}$ and q exponents); $X_{1}, X_{2}$ and $X_{3}$ are the $\log F_{z}, \log M_{z}$, and $\log$ f values, respectively; and the error term is $\varepsilon$. In Eq. 3, $\beta_{0}$ and $\mathrm{X}_{0}$ have been used to calculate the "c" value according to the uncoated or coated drills; in addition, $X_{0}$ is defined as an imaginary factor and is supposed to be 1 .

Equation 3 consists of three independent variables $\left(x_{1}, x_{2}\right.$ and $\left.x_{3}\right)$ and a dependent one (y). Regression analysis was used to solve Equation 1. Moreover, a regression model was used to make calculations and predictions about the subject. Equation 3 is suitable for multiple linear regression analysis. Therefore, the prediction of coefficients $B_{0}, B_{1}, B_{2}, B_{3}$ and $B_{4}$ was solved by the least squares method. Accordingly, the matrix form of Equation 3 is indicated for each of the drill types as follows:

$$
\begin{aligned}
& Y=\left[\begin{array}{c}
Y_{1} \\
Y_{2} \\
\ldots \\
Y_{n}
\end{array}\right], B=\left[\begin{array}{l}
\beta_{1} \\
\beta_{2} \\
\ldots \\
Y_{n}
\end{array}\right], e=\left[\begin{array}{l}
e_{1} \\
e_{2} \\
\ldots \\
e_{n}
\end{array}\right] \text { and } X=\left[\begin{array}{cccc}
1 & X_{11} & . . & X_{K 1} \\
1 & X_{22} & . . & X_{K 2} \\
. & . . & . . & . . \\
1 & X_{2 n} & . . & X_{K n}
\end{array}\right] \\
& Y=X \cdot B+e
\end{aligned}
$$

where $\mathrm{K}$ and $\mathrm{n}$ are the number of drilling processes and the number of analyses, respectively; $\mathrm{Y}$ is " $\mathrm{n} * 1$ " the dependent variable vector, $\mathrm{X}$ is " $\mathrm{n} * \mathrm{~K}$ " the independent variables of the matrix, B is " $\mathrm{K} * 1$ " the vector of model constants; and e is " $\mathrm{n} * 1$ " the vector of error terms. For minimizing the sum of the squares of differences between the practical values (specified by Ansys) obtained by the least squares method and the calculated theoretical values, the prediction of parameters (model vector of constants) is found in the multiple linear regression analysis. If necessary, regulations are made accordingly; the solution required for the calculation of the $\mathrm{m}, \mathrm{n}, \mathrm{p}$, and $\mathrm{q}$ exponents for the model constant vector, and hence the feed force, shear force, moment, and feed quantity, for uncoated and coated drills, is given in Equation 5:

$$
\mathrm{B}=\left[\mathrm{X}^{\prime} \mathrm{X}\right]^{-1} \mathrm{X}^{\prime} \mathrm{Y}
$$

In Equation 5, $\mathrm{X}^{\prime}$ is the transposition of the independent variable matrix $\mathrm{X},\left[\mathrm{X}^{\prime} \mathrm{X}\right]$ is the inverse matrix, and $\mathrm{Y}$ denotes the vector values (consisting of $\log \mathrm{R}_{\mathrm{i}}$ ) determined by the multiplication help of the ANSYS Workbench. The mean absolute percentage error (MAPE) criteria, the root mean square (RMS) criteria, and the coefficient of determination $\left(\mathrm{R}^{2}\right)$ are all used to determine the compatibility of the real analysis results. Moreover, the error values (\%) of all the stress and the total deformation values were determined by the model.

$$
M S E=\frac{1}{p} \sum_{i} e_{i}^{2}=\frac{1}{p} \sum_{i}\left(t_{i}-o_{i}\right)^{2}
$$




$$
\begin{aligned}
& R M S=\sqrt{M S E}=\sqrt{\frac{1}{p} \sum_{i} e_{i}^{2}}=\sqrt{\frac{1}{p} \sum_{i}\left(t_{i}-o_{i}\right)^{2}} \\
& R^{2}=1-\left(\sum_{i}\left(t_{i}-o_{i}\right)^{2} / \sum_{i}\left(t_{i}-\bar{t}\right)^{2}\right) \\
& \% . \text { Error }=\frac{\left|t_{i}-o_{i}\right|}{t_{i}} \times 100 \\
& M A P E=\frac{1}{p} \sum_{i} \frac{\left|t_{i}-o_{i}\right|}{t_{i}} \times 100
\end{aligned}
$$

In Equations 6-10, $\mathrm{e}_{\mathrm{i}}, \mathrm{t}_{\mathrm{i}}, \mathrm{o}_{\mathrm{i}}, \mathrm{p}$, and $\bar{t}$ are, respectively, the error, the analysis result, the modelling result, the number of samples, and the average value of the analysis result. The total percentage of error (\%) for all samples is calculated as the maximum percentage of error $\left(\mathrm{e}_{\max } \%\right)$. Dividing the total percentage of errors by the number of samples, the MAPE values were calculated. The RMS convergence value with 0 in Equation 7 was used as a criterion to indicate the performance rate. The $\mathrm{R}^{2}$ in Equation 8 shows the relationship between the model results and the experimental results. The performance of the developed model increases as the $\mathrm{R}^{2}$ value is closer to 1 . The low MAPE value points out that the model is feasible.

\section{Results and discussion}

\subsection{Experimental results}

The thrust force values of the coated and uncoated drills during drilling the AISI H13 steel are given in Figure 1a, the cutting force values in Figure 1b, and the drilling torque values in Figure 1c; the uncoated and coated tools are indicated as ' $U C$ ' and ' $\mathrm{CO}$ ', respectively. When the graphs in Figure 1 are examined, one can see that the thrust force, the theoretically calculated cutting force [15], and the drilling torque increase with an increase in the feed rate. This can be explained by the increasing volume of chips removed per unit of time with the increasing feed rate. Higher cutting speeds lead to an increase in the thrust force in operations with the uncoated drills, while in those with the coated drills, there is a reduction in the thrust force.

Here, the earlier loss of the cutting ability of the uncoated drill tip with increasing cutting speed explains why stronger thrust force was used to cover the distance along the axis of the drill hole in the required unit of time. When the cutting speed was increased, the high wear resistance of the coated drills can account for the fact that the chip was deformed with a less strong force (Figure 1a). In the drilling operations, when the cutting speed was increased, both uncoated and coated drill bits showed a reduction in the torque and the drilling force. With an increase in the cutting speed, the chip-drilling tool contact area was reduced and less strong cutting force was used to deform the chip; in addition, the faster chip evacuation is thought to have led to reduced cutting forces. Thus, as a result of increased cutting speed, there was a reduction in the magnitude of the cutting forces and the drilling torque (Figure 1). 


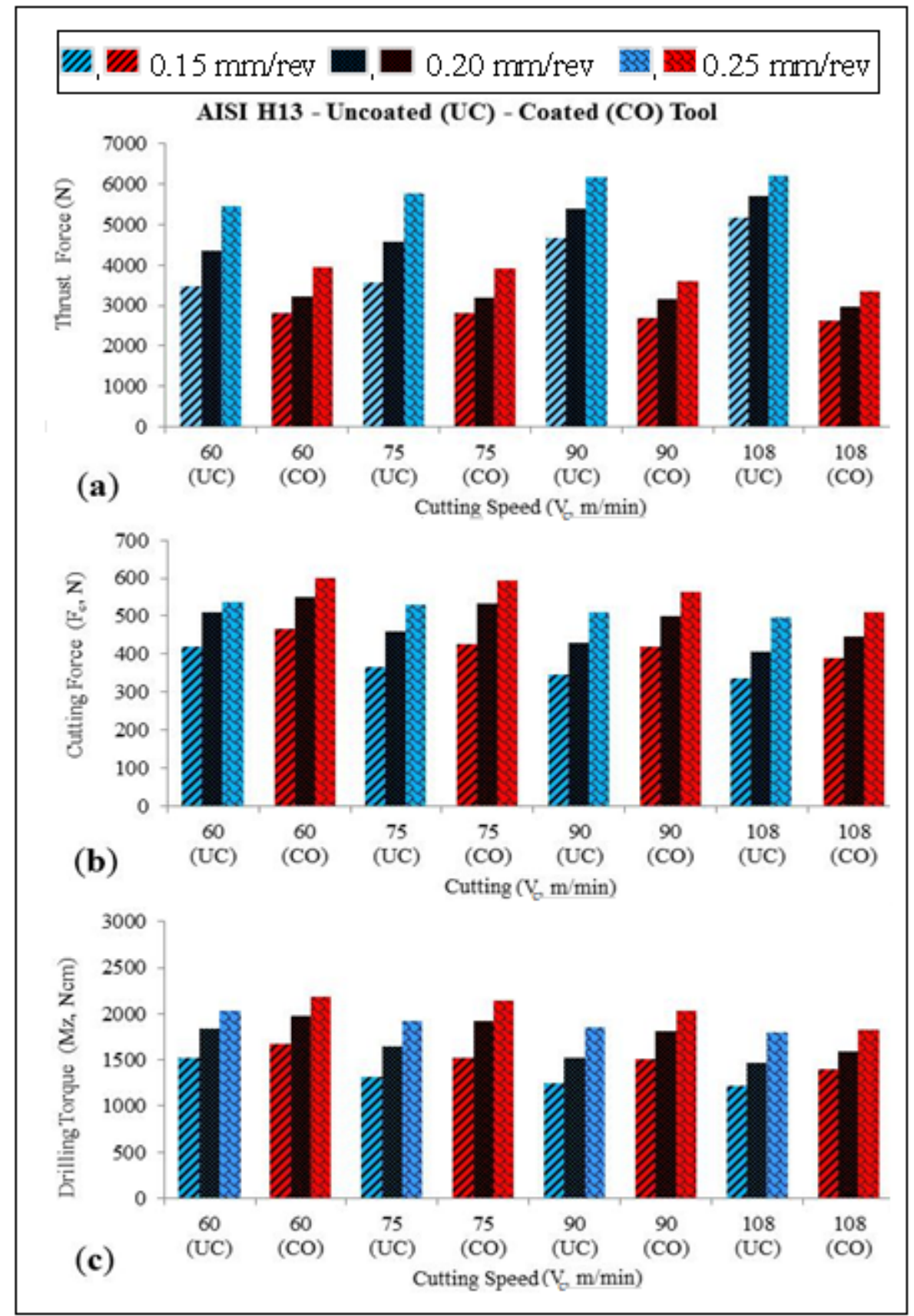

Fig. 1 Comparison of experimental results for uncoated and coated drills

In operations with the uncoated drills, there was an increase in the magnitude of thrust force when the cutting speed was increased, while in those with the coated drill bits, there was a decrease. In operations with the coated drills, the torque and the cutting forces were greater than in operations with the uncoated drills. With an increased cutting speed, the tool wear on the uncoated drills increased.

\subsection{Analysis results}

Results were based on the changes in the cutting parameters, including the drill changes on auxiliary surfaces, the chip surfaces, the cutting edge and the auxiliary cutting edge, the total deformation $(\Delta)$ from the effects of tool wear, the equivalent stress (von-Mises stress, $S_{\text {eqv }}$ ), and the largest and the smallest stress (respectively, $S_{1}$ and $S_{3}$ ). The values of cutting parameters based on the changes in the AISI H13 steel during the drilling are given in Figure 2. 


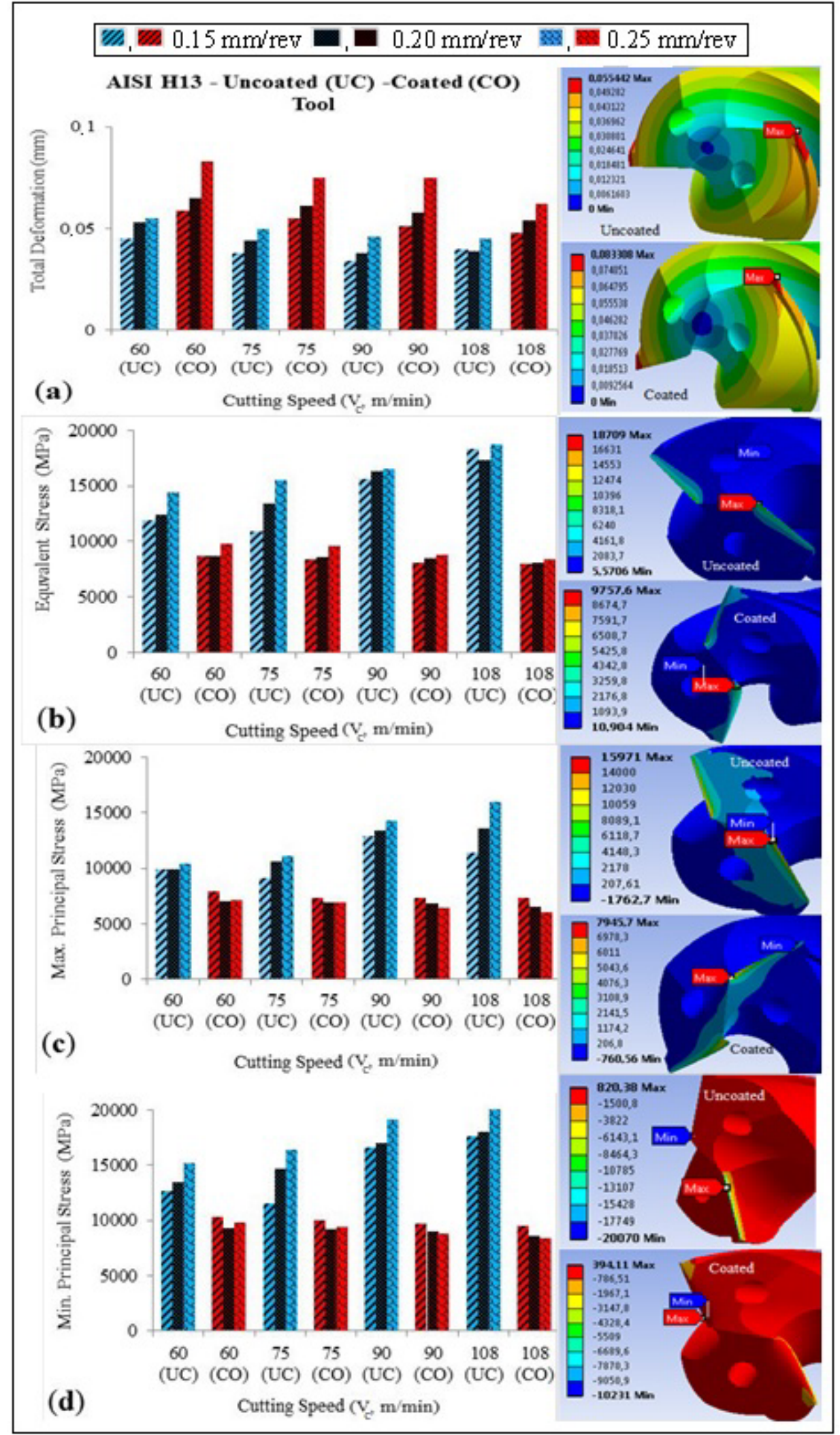

Fig. 2 Comparison of regression results of uncoated and coated drills

Increase in the cutting speed led to a decrease in the total deformation (Figure 2a). With both uncoated and coated drills, the highest feed rate $(0.25 \mathrm{~mm} / \mathrm{rev})$ in combination with the lowest cutting speed $(60 \mathrm{~m} / \mathrm{min})$ produced the maximum total deformation. In that case, the highest volume of chips removed per unit of time was at the maximum feed rate; the slowest 
chip evacuation was at the lowest cutting speed; the removal of chips from the material can be attributed to the cutting conditions with the highest cutting force of the drill. The maximum total deformation occurred in the outermost region of the drill cutting edge, which was the farthest from the centre of the drill. In the process of drilling, since the outermost regions of the drill cutting edges are in coordination with the regions of the cutting edges closest to the drill centre, the tool-chip contact is longer. Therefore, the reason for the greater length of the chip-tool friction and for the maximum volume of chip removal per unit of time was the fact that the total deformation was greatest in that part of the drill. The graphs in Figure 2 map the equivalent stress values derived from analyses of the photographs of AISI H13 steel cut with uncoated and coated drills. In the drilling process, the equivalent stress $\left(\mathrm{S}_{\text {eqv }}\right)$ values of the drills rose at increasing feed rates. In that case, the increase in the feed rate per unit of time can be explained by the increased volume of removed chips. During the chip removal, as we get closer to the centre of the drill, the peripheral speed decreases and the rake angle is reduced. Because of the smaller rake angle, the chips are crushed and removed from this part of the drill [16]. Therefore, the drill worked to crush and remove the chips at a low peripheral speed due to difficulties in evacuating the chips near the drill centre, which exposed this region to more stress. Consequently, the maximum feed rate of the equivalent stress values in the area near the centre of the drill was normal. When evaluating the cutting speed, it was observed that the increased cutting speed led to an increase in equivalent stress in the uncoated drills and to a decrease in the coated drills. In the case of the uncoated carbide drills, wear increased with an increasing cutting speed; the high performance of the coated drills can be attributed to the characteristics of the drill material. In drilling operations, when the cutting speed was increased, increased wear occurred in the uncoated drills in areas close to the drill centre.

During drilling, the rapidly increasing drill wear resulting from the drill motion along the hole axis to remove chips caused the drill to become overloaded and subjected to additional stress. For this reason, the highest equivalent stress value was realized at a feed rate of $0.25 \mathrm{~mm} / \mathrm{rev}$ in combination with a cutting speed of $108 \mathrm{~m} / \mathrm{min}$. The photograph in Figure 3 shows the uncoated drill and the chip resulting from the drilling operation. It can be observed that the experimental work agrees with the results of the analysis.

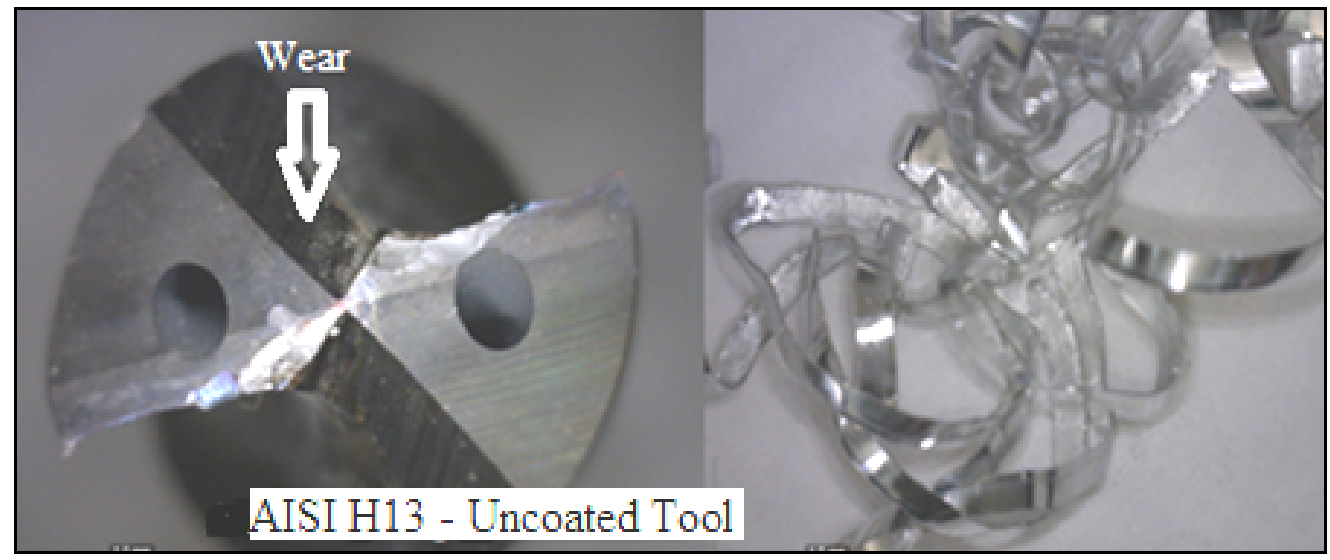

Fig. 3 Uncoated tool and chip form.

With an increasing cutting speed, there was a reduction in the level of equivalent stress in the coated drill. The increase in the cutting speed can explain the reduction in the cutting force shown in the operations using coated drills. The cutting forces were reduced as a result of the increasing ease of chip deformation and the reduction in the tool-contact area when the 
cutting speed was increased. Furthermore, the lack of wear with the increase in the cutting speed was due to the faster chip evacuation and the characteristics of the coating material on the drill (Figure 4), which also led to a further reduction in the magnitude of cutting forces. That reduction ensured less equivalent stress in the drill. The evacuation of the maximum volume of chips was the most difficult at the highest feed rate $(0.25 \mathrm{~mm} / \mathrm{rev})$ combined with the lowest cutting speed $(60 \mathrm{~m} / \mathrm{min})$; therefore, the drill was expected to remain exposed to the greatest stress value as a result.

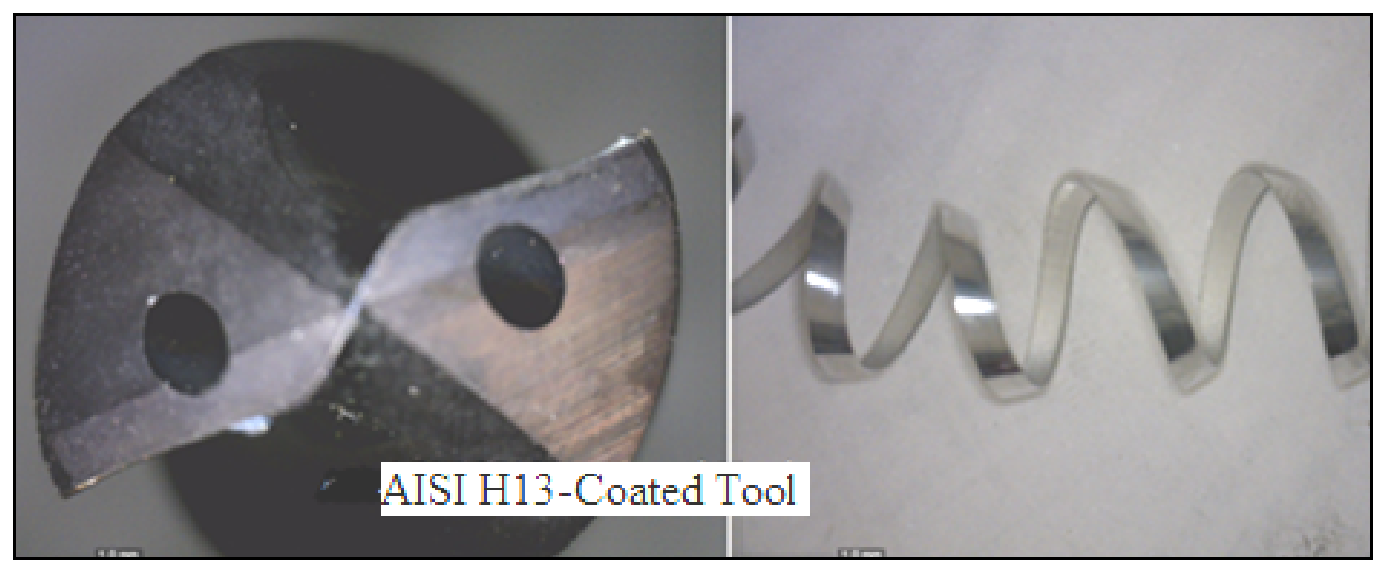

Fig. 4 Coated tool and chip form

Figure $5 \mathrm{c}$ and $\mathrm{d}$ show the $\mathrm{S}_{1}$ and $\mathrm{S}_{3}$ stresses in the uncoated drill with respect to the increases in the cutting speed and the feed rate. Here, the increased wear of the uncoated drill with the increases in the feed rate and the cutting speed can be explained by the use of extra force needed to remove the increased volume of chips and to advance along the axis of the drill hole. With increased cutting forces, chip evacuation was more difficult, and the operation to crush and remove the chips led to extreme stress in the area near the centre of the drill. The $S_{3}$ stress, which was greater than $S_{1}$, indicated that this end of the drill was more exposed to compressive stress than to tensile stress. In the coated drill, the increase in the cutting speed and the feed rate led to reductions in both the $S_{1}$ and $S_{3}$ stresses. Thus, the difficult chip evacuation due to the low feed rate was attributed to the prolonged chip-tool contact at the lowest cutting speed. As a result of the analysis made on the coated drills, the cutting conditions for both the $S_{1}$ and $S_{3}$ stresses were determined as the lowest feed rate $(0.15 \mathrm{~mm}$ $/ \mathrm{rev}$ ) with the lowest cutting speed $(60 \mathrm{~m} / \mathrm{min})$. With the increase in the cutting speed, chip evacuation was facilitated in the coated drill with less friction due to its high wear resistance and low friction coefficient. The lack of wear on the drill and the easy chip evacuation along with the reduction in the magnitude of forces acting on the drill caused the reduction in the $S_{1}$ and $S_{3}$ stresses despite the increase in the cutting speed. From the perspective of the $S_{1}$ and $S_{3}$ stresses, compressive stress was seen to be more effective, as with the uncoated drills.

\subsection{Modelling results}

In the modeling process, the exponent values $\mathrm{m}, \mathrm{n}, \mathrm{p}$ and $\mathrm{q}$ and the constant $\mathrm{c}$, as specified in Equation 1, were determined for each type of drill via Equation 5. The model constants and exponent values were calculated together with other statistical evaluation information (MSE, RMS, $\mathrm{R}^{2}, \%$ emax, MAPE) for the uncoated carbide drills (Table 4) and the coated drills (Table 5). In the processing of AISI H13 steel, the results obtained from the analysis and those from the model were converted to graphs and are shown collectively for the uncoated and coated drills in Figure 5. In the graphs, the results of the analysis are 
indicated by (A) and the results of the model by (M). When the graphs in Figure 5 are examined, it can be seen that during drilling with the uncoated and coated drills, the results of the total deformation and stress analysis were similar to the results of the model. In operations with the uncoated carbide drill, in both the analysis and the model results, values for $\Delta, \mathrm{S}_{\text {eqv }}$, $\mathrm{S}_{1}$ and $\mathrm{S}_{3}$ increased with the increasing feed rate. While the total deformation $(\Delta)$ decreased with an increased cutting speed, (Figure 5a), the $S_{\text {eqv }}, S_{1}$ and $S_{3}$ stress values rose with an increase in the cutting speed (Figure 5c, e and g). As in the analysis results for the uncoated carbide drills, the model results also showed that $\Delta, \mathrm{S}_{\text {eqv }}, \mathrm{S}_{1}$, and $\mathrm{S}_{3}$ were higher at the highest feed rate in order for the drills to advance along the axis of the drill hole, proving that they were subjected to overload and stress. Despite the reduction in the total deformation with an increased cutting speed, the chip load was low. As the cutting speed was increased, the $S_{\text {eqv }}$, $\mathrm{S}_{1}$, and $\mathrm{S}_{3}$ stresses increased and the drill tip area went through an accelerated wear process, which indicated that it had been exposed to extreme stresses. The fact that $\mathrm{S}_{3}$ was greater than $\mathrm{S}_{1}$ indicated that there was more compressive stress on the drill. On the uncoated drill, the parameters of feed rate and cutting speed were the most significant factors for the total deformation $(\Delta)$ and the $\mathrm{S}_{\text {eqv }}, \mathrm{S}_{1}$, and $\mathrm{S}_{3}$ stresses.

Table 4 Calculated model constants and other statistical information for the uncoated drills

\begin{tabular}{|l|l|l|l|l|}
\hline \multicolumn{5}{|c|}{$R_{i}=c \cdot F_{z} \cdot m \cdot F_{c} \cdot n \cdot M_{z} \cdot p \cdot f \cdot q$} \\
\hline & $\Delta$ & $\mathrm{S}_{\mathrm{eqv}}$ & $\mathrm{S}_{1}$ & $\mathrm{~S}_{3}$ \\
\hline $\mathrm{c}$ & $1.71096 \mathrm{E}-12$ & $4.0268 \mathrm{E}-05$ & $5.561 \mathrm{E}-06$ & 0.0005 \\
\hline $\mathrm{m}$ & 0.274 & 1.598 & 1.7 & 1.604 \\
\hline $\mathrm{n}$ & -1.44 & 0.697 & 0.9470 & 1.34 \\
\hline $\mathrm{p}$ & 2.988 & -0.254 & -0.1706 & -0.697 \\
\hline $\mathrm{q}$ & -0.9 & -1.307 & -1.7679 & -1.255 \\
\hline MSE & $2.369 \mathrm{E}-06$ & 430112.367 & 178314.2 & 465864.6 \\
\hline RMS & 0.00015 & 255.829 & 422.272 & 282.542 \\
\hline $\mathrm{R}^{2}$ & 0.967 & 0.977 & 0.956 & 0.984 \\
\hline$\%$ emax & 1.065 & 1.842 & 2.829 & 1.624 \\
\hline MAPE & 0.997 & 1.77 & 2.599 & 1.098 \\
\hline
\end{tabular}

The graphs in Figure 5 show that an increase in the feed rate in operations using both uncoated and coated drill bits caused an increase in the total deformation.

The data obtained as a result of the modeling for the uncoated drills are displayed in Table 4 . The RMS value of $\Delta(\mathrm{RMS}=0.000153922)$ which approaches zero and, especially, the coefficient $R^{2}\left(R^{2}=0.96\right)$ which approaches 1 suggest that the results of the model were compatible with the analysis results. As for the $\mathrm{S}_{\text {eqv }}, \mathrm{S}_{1}$, and $\mathrm{S}_{3}$ stresses, the situation was similar. For $\mathrm{S}_{\text {eqv }}$, the $\mathrm{R}^{2}$ reliability coefficient was 0.97 and the model error margin (MAPE) was 1.77; for $\mathrm{S}_{1}, \mathrm{R}^{2}$ was 0.95 and MAPE 2.59; and for $\mathrm{S}_{3}, \mathrm{R}^{2}$ was 0.98 and MAPE 1.09; $\mathrm{R}^{2}$ reliability coefficients approaching 1 indicate that the results of the analysis and of the model are compatible. MAPE was between $0.98 \%$ and $2.59 \%$, indicating that the model is applicable. 


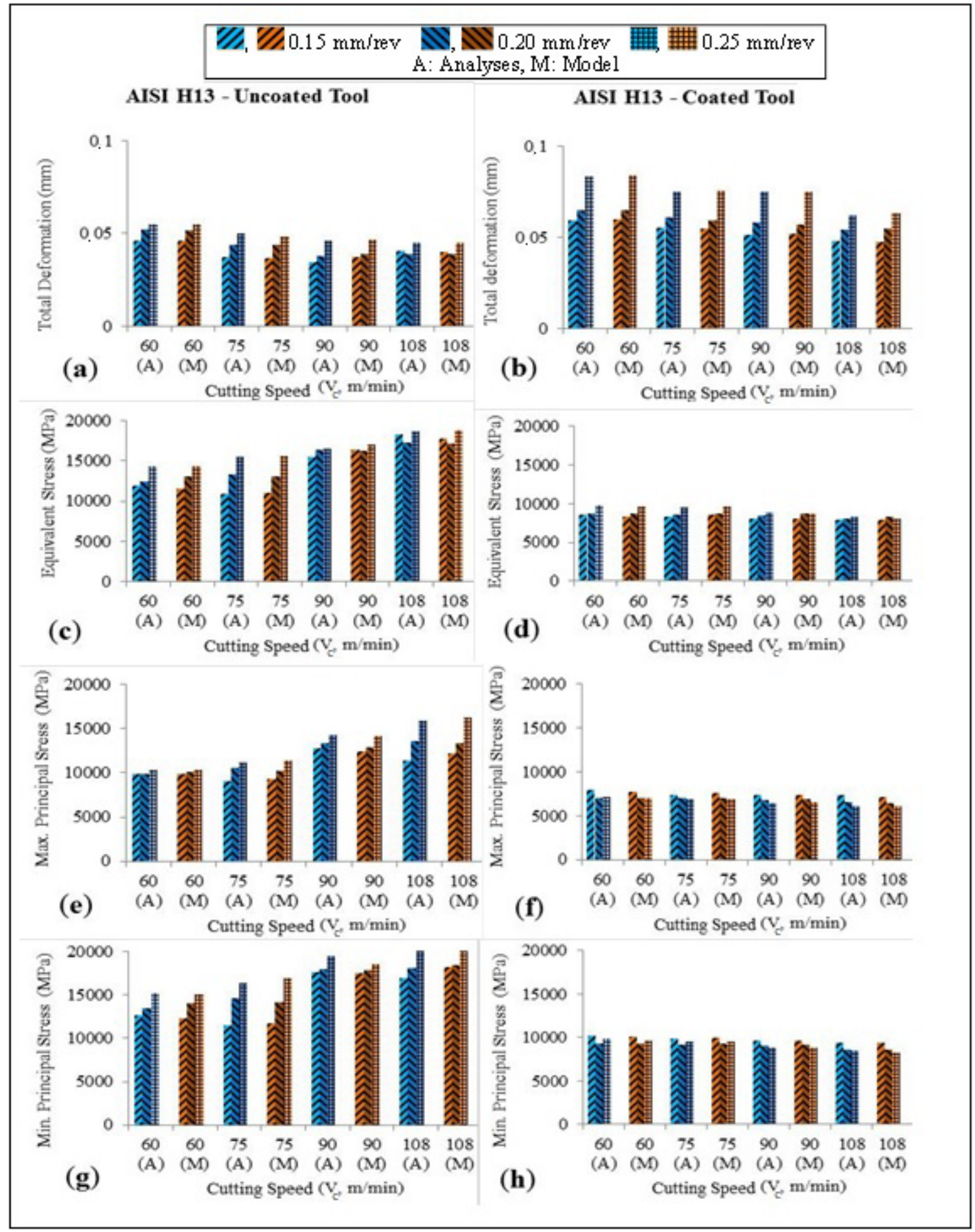

Fig. 5 A comparison of model results with the results of analysis

Figure 5 illustrates the stresses in the coated drills; the results of the analysis and the results of the model seem to be compatible. In the results of both the analysis and the model, while $\Delta$ and $\mathrm{S}_{\text {eqv }}$ increase with an increasing feed rate, $\mathrm{S}_{1}$ and $\mathrm{S}_{3}$ are reduced. Thus, with the increased $\Delta$ of the chip load due to the increasing feed rate, the increasing $S_{\text {eqv }}$ is more effective; the reduction in the values of the $S_{1}$ and $S_{3}$ stresses with an increasing feed rate can be explained by the minimization of the tool-chip contact. With an increased cutting speed, $\Delta$, $\mathrm{S}_{\text {eqv }}, \mathrm{S}_{1}$ and $\mathrm{S}_{3}$ showed a tendency to decrease. In that case, the increasing cutting speed could explain the acceleration of the chip evacuation and the reduced cutting forces. The $\mathrm{S}_{3}$ stress in 
the drill was greater than the $S_{1}$ stress, which suggested that the compressive stress was effective. In the coated drill, for $\Delta, \mathrm{S}_{\text {eqv }}, \mathrm{S}_{1}$ and $\mathrm{S}_{3}$, the cutting speed was seen as the most significant parameter. The close correspondence of the results of the analysis with the results of the model confirmed the accuracy of the procedure.

Table 5 Calculated model constants and other statistical information for the coated drills.

\begin{tabular}{|l|l|l|l|l|}
\hline \multicolumn{5}{|c|}{$R_{i}=c \cdot F_{z} \cdot m \cdot F_{c} \cdot n \cdot M_{z} \cdot p \cdot f \cdot q$} \\
\hline & $\Delta$ & $\mathrm{S}_{\mathrm{eqv}}$ & $\mathrm{S}_{1}$ & $\mathrm{~S}_{3}$ \\
\hline $\mathrm{c}=$ & 179327.5 & 17.254 & 0.0088 & 0.781 \\
\hline $\mathrm{m}=$ & 3.482 & 1.5793 & 0.539 & 0.979 \\
\hline $\mathrm{n}=$ & 9.443 & 1.3 & -1.717 & -0.206 \\
\hline $\mathrm{p}=$ & -10.503 & -1.615 & -1.717 & -0.167 \\
\hline $\mathrm{q}=$ & -0.779 & -0.775 & -0.678 & -0.697 \\
\hline $\mathrm{MSE}=$ & $3.48821 \mathrm{E}-05$ & 27456.6 & 12386.34 & 9900.53 \\
\hline $\mathrm{RMS}=$ & 0.0009 & 165.7 & 111.29 & 99.5 \\
\hline $\mathrm{R}^{2}=$ & 0.959 & 0.98 & 0.965 & 0.963 \\
\hline$\%$ emax $=$ & 1.401 & 1.858 & 2.396 & 1.694 \\
\hline MAPE $=$ & 0.9843 & 0.728 & 1.202 & 0.8565 \\
\hline
\end{tabular}

The results obtained from the modelling of the drilling operation with the coated drills are given in Table 5. The values of the $\mathrm{R}^{2}$ coefficient of determination for $\Delta, \mathrm{S}_{\text {eqv }}, \mathrm{S}_{1}$ and $\mathrm{S}_{3}$ were between 0.98 and 0.95 , showing that the values of the model were in agreement with the analysis results. The model error of $1-2 \%$ is within acceptable limits, showing that the same conditions used for the model can be applied to drilling operations.

\section{Conclusions}

Experimental studies into the stresses that were developed in uncoated and coated drills during the drilling of AISI H13 steel were performed; the results were analysed and compared to those of the model developed for that research. As a result of the study, the following conclusions were reached:

In all procedures with uncoated and coated drills, it was determined that the thrust force and the torque increased with an increasing feed rate. Since the increased cutting speed in operations with uncoated drills accelerated the wear, the increased thrust force led to a decrease in torque. The increased cutting speed in operations carried out with the coated drills was seen to decrease both the thrust force and the torque.

According to the results of the analysis, the total deformation increased with an increasing feed rate in both the uncoated and coated drills. Because the coated drills were exposed to higher chip load compared to the uncoated drills, larger total deformation occurred with the coated drills. The increase in the cutting speed was the cause of a decrease in the total deformation.

The $S_{\text {eqv }}, S_{1}$, and $S_{2}$ stresses occurring in the uncoated drills increased along with the increase in both the cutting speed and the feed rate. In this case, when the cutting speed was increased, the increased tool wear created by greater cutting forces was attributed to the increased volume of chip removal per unit of time at an increasing feed rate. 
In the coated drill, it was observed that despite the increasing cutting speed and feed rate, the equivalent stress and the maximum and the minimum stresses decreased. Regardless of increases in the cutting speed, the prolongation of the tool-chip contact decreased with an increasing feed rate. Lower values of cutting forces were thought to be the source of this decrease. The minimum stress was greater than the maximum stress in both the uncoated and coated drills. Furthermore, the thrust force was greater than the cutting force; this can be attributed to the greater exposure of the drill to compressive stress during the drilling operations.

In particular, since the developed mathematical model coefficients $\left(\mathrm{R}^{2}\right)$ were between 0.96 and 0.98 , and the mean average percentage error (MAPE) of the model was between 0.8 and 2.5 , the results of the analysis were compatible with the results of the model. Thus, the results of the developed model are highly reliable and can be applied for the prediction of cutting parameters

\section{REFERENCES}

[1] Türkiye Osmanlı Alaşımlı Çelikler San. ve Tic. Ltd. Şti. Takım Çeliklerinde Elementlerin Etkisi (In Turkish), from http://www.osmanli-bohler.com/upload/pdf/teknik bilgiler/Takim_Celikleri.pdf accessed on 2017-11-16.

[2] Basso RLO, Pastore HO, Schmidt V, Baumvol IJR, Abarca SAC Microstructure and Corrosion Behaviour of Pulsed Plasma-Nitrided AISI H13 Tool Steel. Corrosion Science, (2010) 52:3133-3139. https://doi.org/10.1016/j.corsci.2010.05.036

[3] Genel K Boriding Kinetics of AISI H13 Steel. Vacuum, (2006) 80: 451-457. https://doi.org/10.1016/j.vacuum.2005.07.013

[4] Oliveira CKN, Riofano RMM, Casteletti LC Formation of Carbide Layers on AISI H13and D2 Steels by Treatment in Molten Borax Containing Dissolved Both $\mathrm{Fe}-\mathrm{Nb}$ and $\mathrm{Fe}-\mathrm{Ti}$ Powders. Science Direct, Materials Letters, (2005) 59: 1719-1722. https://doi.org/10.1016/j.matlet.2005.01.052

[5] Kheirandish S, Noorian A Effect of Niobium on Microstructure of Cast AISI H13 Hot Work Tool Steel. Journal of Iron and Steel Research International, (2008) 15: 4, 61-66. https://doi.org/10.1016/S1006706X(08)60145-4

[6] Umbrello D, Rizzuti S, Outeiro JC, Shivpuri R, M'Saoubi R Hardness-Based Flow Stress for Numerical Simulation of Hard Machining AISI H13 Tool Steel. Journal of Material Processing Technology, (2008) 199: 64-73. https://doi.org/10.1016/j.jmatprotec.2007.08.018

[7] Yan, H, Hua J, Shivpuri R Flow Stress of AISI H13 Die Steel in Hard Machining. Materials and Design, (2007) 28: 272-277. https://doi.org/10.1016/j.matdes.2005.06.017

[8] Brandao LC, Coelho RT, Lauro CH (2011) Contribution to Dynamic Characteristics of the Cutting Temperature in the Drilling Process Considering One Dimension Heat Flow. Applied Thermal Engineering, 33: 3806-3813. https://doi.org/10.1016/j.applthermaleng.2011.07.024

[9] Kaynak, Y., (2006) Matkap ile Delik Delme Esnasında Kesme Parametrelerinin Kesme Kuvveti ve Sıcaklığın Değişimine Etkisinin Deneysel Olarak İncelenmesi. Master’s Thesis Dissertation, Marmara University

[10] Sousa P FB, Borges VL, Pereira IC, Silva MB, Guimarães G Estimation of Heat Flux and Temperature Field During Drilling Process Using Dynamic Observers Based on Green's Function. Applied Thermal Engineering, (2012) 48:144-154. https://doi.org/10.1016/j.applthermaleng.2012.04.061

[11] Şekerci KN, Duran A, Şeker U, Yağmur S (2012) AISI 316L Malzemesinin Delinmesinde Kesme Parametrelerinin Kesme Bölgesi Sıcaklığı Üzerindeki Etkisi (In Turkish). III.Ulusal Talaşlı İmalat Sempozyumu, Ankara

[12] Almeida FA, Carrapichano JM, Fernandes AJS, Sacramento J, Silva RF, Oliveira FJ Nanocrystalline CVD Diamond Coatings for Drilling of WC-Co Parts. Int. Journal of Refractory Metals and Hard Materials, (2011) 29: 618- 622. https://doi.org/10.1016/j.ijrmhm.2011.04.008

[13] Özkul İ, Buldum BB, Akkurt A Dievar Sıcak İs Takım Çeliğinin Delinmesinde Kesme Parametrelerinin Kesme Kuvvetleri ve Yüzey Kalitesine Etkisinin Regresyon Analiziyle Modellenmesi Pamukkale Üniversitesi Mühendislik Bilimleri Dergisi, (2013) 1:1,1-9. https://doi.org/ 10.5505/pajes.2013.69885 
[14] Afazov SM, Ronaldo R, Londsdale D, Zdebski D, Ratchev SM Analysis of Micro-Drilling of Glassy Ceramic Macor Nozzles for Scanning Droplet Systems, Journal of Materials Processing Technology, (2013) 213:.221-228. https://doi.org/10.1016/j.jmatprotec.2012.08.011

Submitted: $\quad$ 14.7.2017

Accepted: $\quad 31.01 .2018$
Dr. İsmail Tekaüt

Technical Sciences Vocational School, Department of Machine, Gazi University, Ankara Turkey

Prof. Dr. Hali Demir

Karabük University Faculty of Technology Karabuk/TURKEY

Prof.Dr. Ulvi Şeker

Department of Manufacturing Engineering Gazi University Faculty of Technology 06500 Teknikokullar Ankara Turkey 